\title{
The Isolation of Rhapidosomes from the Blue-green Alga, Spirulina
}

\author{
By HELEN Y. Y. CHANG AND MARY M. ALLEN \\ Department of Biological Sciences, Wellesley College, \\ Wellesley, Massachusetts 02181, U.S.A.
}

(Received 27 July 1973)

\begin{abstract}
SUMMAR Y
Rhapidosomes, similar to those found in the flexibacterium Saprospira, have been isolated in the blue-green algal counterpart of Saprospira, Spirulina. They have been partially purified by renografin density gradients and shown to contain protein and a negligible amount of nucleic acid. Mitomycin $\mathrm{C}$ induction causes an increase in the number of rhapidosomes as well as an increase in the number of intact rhapidosome particles.
\end{abstract}

\section{INTRODUCTION}

Rod-shaped particles termed rhapidosomes were first observed and characterized by Lewin in autolysates of the flexibacterium Saprospira grandis (Correll \& Lewin, 1964). These particles were demonstrated by negative staining under the electron microscope to be hollow cylinders $260 \mathrm{~nm}$ long, with or without a central wick-like cylinder (usually $300 \times 15 \mathrm{~nm}$ ) extending out of one end of the sheath. The wicks were constructed of six parallel elements while the sheath had a helical substructure with spiral subunits separated by $3.5 \mathrm{~nm}$ (Reichle \& Lewin, 1968). Rhapidosomes, after isolation from actively growing cells lysed with chloroform in distilled water and purification by caesium chloride densitygradient centrifugation, were characterized by chemical analysis and u.v.-absorption spectroscopy (Reichle \& Lewin, I968). Intact particles had a sedimentation coefficient of $250 \mathrm{~s}$, aborption peaks at 246 to $250 \mathrm{~nm}$ and 282 to $284 \mathrm{~nm}$, and the usual amino acids. Although the presence of RNA was first reported in the rhapidosomes, later investigators proved that no or insignificant amounts of nucleic acid were present (Delk \& Dekker, 1969; Price \& Rottman, 1970).

How rhapidosomes originate in the cell is not clear, but there are indications that developing rhapidosomes are closely associated with the nuclear region (Lewin \& Kiethe, 1965). Free rhapidosomes are abundant only in the cytoplasm of degenerated cells. The observation that strains which produce rhapidosomes are prone to lysis after the logarithmic phase of growth suggested that the particles are pathogens (Delk \& Dekker, 1972). However, all attempts to demonstrate infectivity or toxicity in potential hosts have been unsuccessful.

Submicroscopic, rod-shaped particles, similar in appearance to rhapidosomes, have been found in a number of procaryotic microbes such as Myxobacter (Reichenbach, I967), Chrondrococcus (Pate, Johnson \& Ordal, 1967), Proteus (van Iterson, Hoeniger \& van Zanten, 1967), Pseudomonas (Yamamoto, 1967), and Chromobacterium (Rucinsky \& Cota-Robles, 1973). Rhapidosomes are similar to a monocin described in Listeria (Bradley \& Dewar, 1966), to the tail core of the contracted tail sheath of the bacteriophage $\mathrm{T}_{4}$ (Moody, 1967), and to the defective phage found in Archangium violaceum (Reichenbach, I967). 
The present investigation demonstrates, for the first time, rhapidosomes in a blue-green alga, Spirulina, an organism which is closely related to the colourless bacterium, Saprospira.

\section{METHODS}

Culture organism. The experimental procedures were carried out with a pure culture of Spirulina strain 63I 3 from the Berkeley culture collection, grown in liquid mineral no. I I medium (Allen, 1968) in Erlenmeyer flasks on a rotary shaker or in stationary culture at room temperature, illuminated with cool white fluorescent lights. Cells were harvested two weeks after inoculation.

Isolation of rhapidosomes. Approximately $4 \mathrm{l}$ of culture were harvested by low-speed centrifugation. The pellet was lysed by resuspension in $200 \mathrm{ml}$ of chloroform. The mixture was stirred overnight at $4{ }^{\circ} \mathrm{C}$, cleared of cell debris by low-speed centrifugation, and the pellet obtained was examined under the light microscope. If lysis was incomplete, as indicated by the presence of intact filaments and cells, the pellet was resuspended in distilled water and stirred vigorously at $4{ }^{\circ} \mathrm{C}$, which resulted in immediate and complete cell lysis.

The supernatant of the lysate was centrifuged at $\mathrm{I} 5000 \mathrm{rev} . / \mathrm{min}$ for $15 \mathrm{~min}$ at $4{ }^{\circ} \mathrm{C}$. The pellet, consisting mainly of smaller elements of cell debris, was discarded. The supernatant was centrifuged in a no. 30 head in a Spinco model L ultracentrifuge at $27000 \mathrm{rev} . / \mathrm{min}$ for $0.5 \mathrm{~h}$. A small greenish pellet (crude pellet) which contained rhapidosomes and other cell fragments such as membranes, was resuspended in $0 . \mathrm{I}$ M-phosphate buffer $(\mathrm{pH} 7)$ for $\mathrm{I} 5$ min at $4{ }^{\circ} \mathrm{C}$ before being layered on a 30 to $60 \%(\mathrm{v} / \mathrm{v})$ renografin gradient pre-chilled at $4{ }^{\circ} \mathrm{C}$ for $\mathrm{I} 5 \mathrm{~min}$ according to the method of Tamin \& Gilvarg (1966). Gradients were centrifuged at $23000 \mathrm{rev} . / \mathrm{min}$ in a SW 25 rotor of a Spinco model L ultracentrifuge at $10{ }^{\circ} \mathrm{C}$ for $12 \mathrm{~h}$. Bands were removed, diluted with $0 \cdot \mathrm{I}$ M-phosphate buffer $(\mathrm{pH} 7)$ and concentrated by centrifugation at $40000 \mathrm{rev} . / \mathrm{min}$ for $30 \mathrm{~min}$. Washed pellets were resuspended in a drop of buffer and examined under the electron microscope by means of negativestaining techniques. In some cases, the rhapidosome-rich pellet was treated with $3 \%$ Triton X-100 for $3 \mathrm{~h}$ at $4{ }^{\circ} \mathrm{C}$ before layering on a second 30 to $60 \%(\mathrm{v} / \mathrm{v})$ renografin gradient.

Electron microscopy. Samples were stained using phosphotungstic acid (PTA) according to Huxley \& Zubay (I960). Samples in 0.I M-phosphate buffer ( $\mathrm{pH} 7$ ) were dropped on 200 mesh Formvar-coated copper grids and allowed to settle. PTA containing $0.4 \%(\mathrm{w} / \mathrm{v})$ sucrose was then placed on the grids for $30 \mathrm{~s}$. Grids were examined, after drying, with a Siemens Elmiskop I electron microscope.

Chemical analyses. I. Protein content: Samples of the rhapidosome-rich fraction were analysed by the Lowry-modification of the Folin reaction with bovine serum albumin (Sigma Chemical Co., St Louis, Missouri, U.S.A.) as standard. 2. RNA content: Samples were extracted in phenol as described by Correll \& Lewin (1964), and RNA was analysed by the orcinol reaction. 3. Action of enzymes and solvents: Samples were treated with the following reagents for $24 \mathrm{~h}$ at $25{ }^{\circ} \mathrm{C}$ unless stated otherwise. (i) Organic solvents: $50 \%(\mathrm{v} / \mathrm{v})$ chloroform; $50 \%(\mathrm{v} / \mathrm{v})$ acetone. (ii) Detergents: $2 \%(\mathrm{w} / \mathrm{v})$ sodium dodecyl/sulphate (SDS); I $\%(w / v)$ sodium deoxycholate (SDC); $3 \%(\mathrm{v} / \mathrm{v})$ Triton X-I00, for $3 \mathrm{~h}$ at $4{ }^{\circ} \mathrm{C}$. (iii) Protein denaturant: 8 m-urea. (iv) Enzymes: pronase ( $\mathrm{I}: \mathrm{I} 00, \mathrm{w} / \mathrm{w}$, ratio of enzyme to protein) at $37^{\circ} \mathrm{C}(\mathrm{pH} 7 \cdot 2)$; 0.00I M-phosphate buffer; trypsin and chymotrypsin (I:50, w/w, ratio enzyme to protein); $0.00 \mathrm{I}$ M-tris buffer at $37^{\circ} \mathrm{C}$ ( $\mathrm{pH} \mathrm{8.I);} \mathrm{RNase,} 0 . \mathrm{I} \mathrm{mg} / \mathrm{ml}$ for $2 \mathrm{~h}$ at $30{ }^{\circ} \mathrm{C}$; DNase, $0 . \mathrm{I} \mathrm{mg} / \mathrm{ml}$ for $2 \mathrm{~h}$ at $30^{\circ} \mathrm{C}$. (v) Others: EDTA, O.I $\mathrm{M}$; $\mathrm{NaOH}, \mathrm{O} \cdot \mathrm{I} \mathrm{N}$ at I00 ${ }^{\circ} \mathrm{C}$ and I $\mathrm{N}$ at $25^{\circ} \mathrm{C} ; \mathrm{HCl}$, I N.

Mitomycin induction. Mitomycin C (Sigma) was added to logarithmic-phase cultures to a 


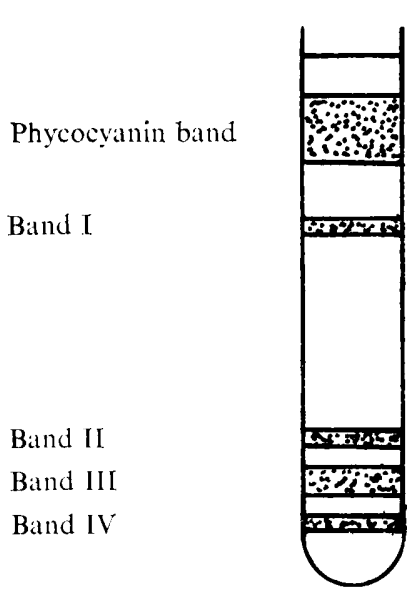

(a)

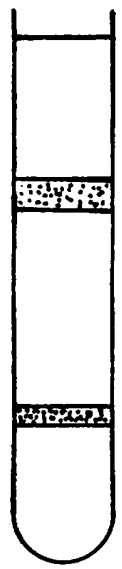

(b)

Fig. I. Renografin density gradients. (a) Gradient layered with crude pellet. Band II is the rhapidosome-rich fraction. (b) Gradient layered with band II after treatment with Triton X-Ioo.

final concentration of $0.5 \mu \mathrm{g} / \mathrm{ml}$. Cultures were centrifuged by low-speed centrifugation after $6 \mathrm{~h}$ and $24 \mathrm{~h}$ of treatment. Both pellet and supernatant were examined under the electron microscope.

\section{Isolation of rhapidosomes}

RESULTS

Fig. I shows two renografin density gradients with their resulting bands. Fig. I $a$ describes a gradient layered with the crude pellet. Below the upper blue band of phycocyanin was a dark green band of small membrane fragments (band I). About two-thirds down the tube there was a pale green band with a tinge of orange (band II) which was seen by electron microscopy to be rich in rhapidosomes. Immediately below this was a green band dotted with dark green aggregates (band III). The lowest band (band IV) was a green band of heavier membrane fragments. No pellet was found at the bottom of the tube. Rhapidosomes were found in all bands, but the number was much greater in band II, and the contaminating membranes were proportionately much less than in the other fractions.

Fig. $\mathrm{I} b$ describes a gradient layered with band II which had been treated with Triton $\mathrm{X}$-IOo to destroy membrane contamination. Two bands were observed: a green band near the top of the tube and a pale orange band at approximately the same position as band II of Fig. I $b$.

\section{Electron microscopy}

Negatively stained preparations of the rhapidosome-rich band (band II) from renografin gradients are shown in Fig. 2. Most of the rhapidosomes appear as sheaths without wicks. The central core stains darker, presumably owing to the penetration of the stain. The hollow cylinders are about $23 \mathrm{~nm}$ in diam with a core of about $7.5 \mathrm{~nm}$. Although most of the rhapdosomes are seen with an empty central canal, thin filaments with a diameter that equals that of the central canal are usually seen near the rhapidosomes (Fig. $2 b$, insert). These wick-like structures are themselves hollow cylinders with a narrow central core of about $2.5 \mathrm{~nm}$ diam.

The length of rhapidosomes varied considerably, ranging from short particles of $100 \mathrm{~nm}$ to long ones of $400 \mathrm{~nm}$. The fact that short rhapidosomes were broken fragments of long 

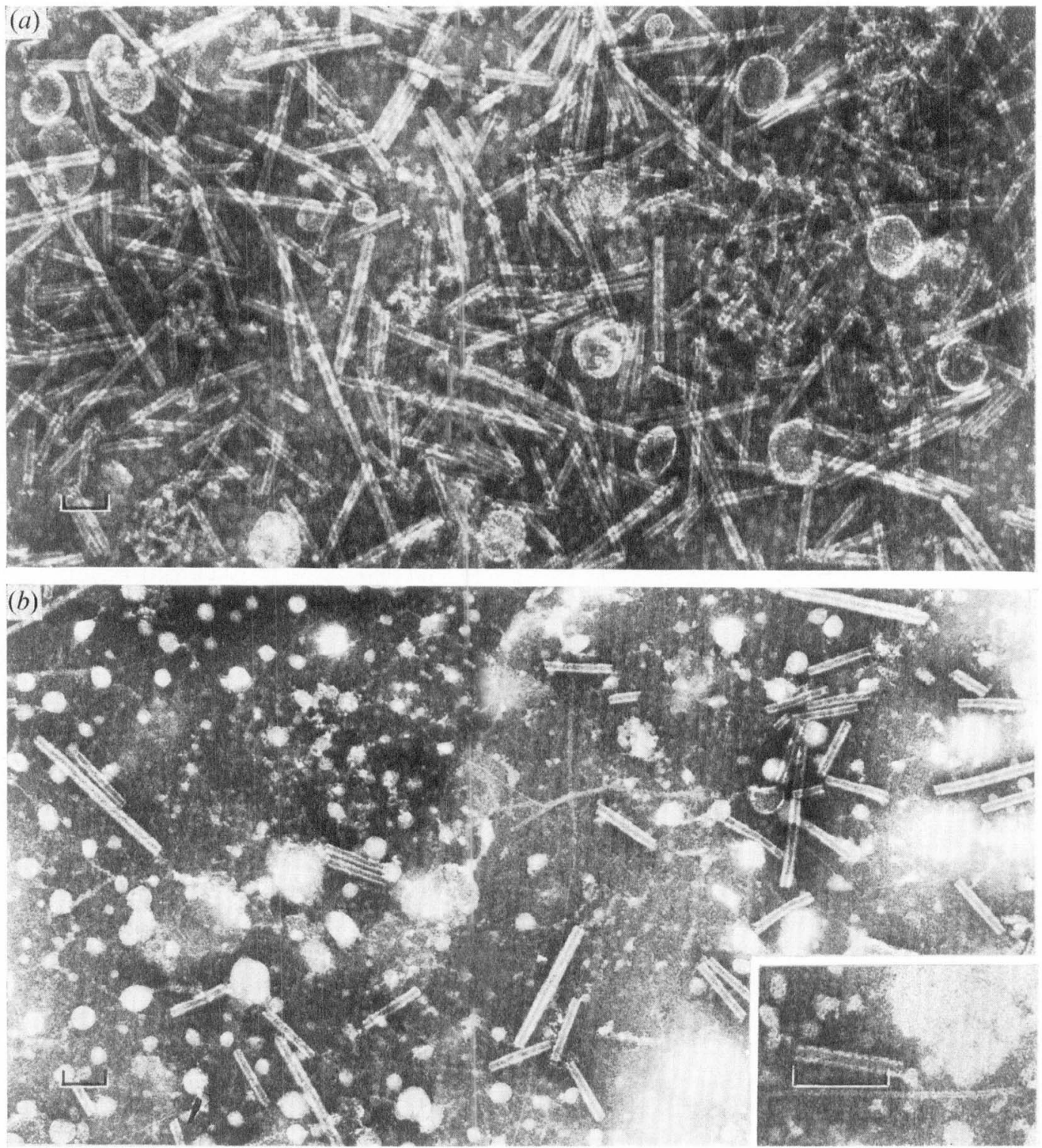

Fig. 2. Negatively stained preparations of the rhapidosome-rich band from renografin gradients (band II). Bar markers $=100 \mathrm{~nm}$.

ones is illustrated in Fig. $3 a$. Although most rhapidosomes had regular ends, some appear to have appendages at one end (Fig. $3 b, d$ ) that may be structures for attachment. Rhapidosomes were usually found in close association with membrane fragments in band II; the main contaminants in the rhapidosome-rich fraction were the small membrane fragments of the photosynthetic membrane system. In some preparations the wicks are seen within the central core of the sheath, sometimes protruding from one end (Fig. $3 \mathrm{c}$ ). In other preparations the wicks partially fill the core (Fig. $3 d$ ) or completely fill the core (Fig. $3 c$ ). 

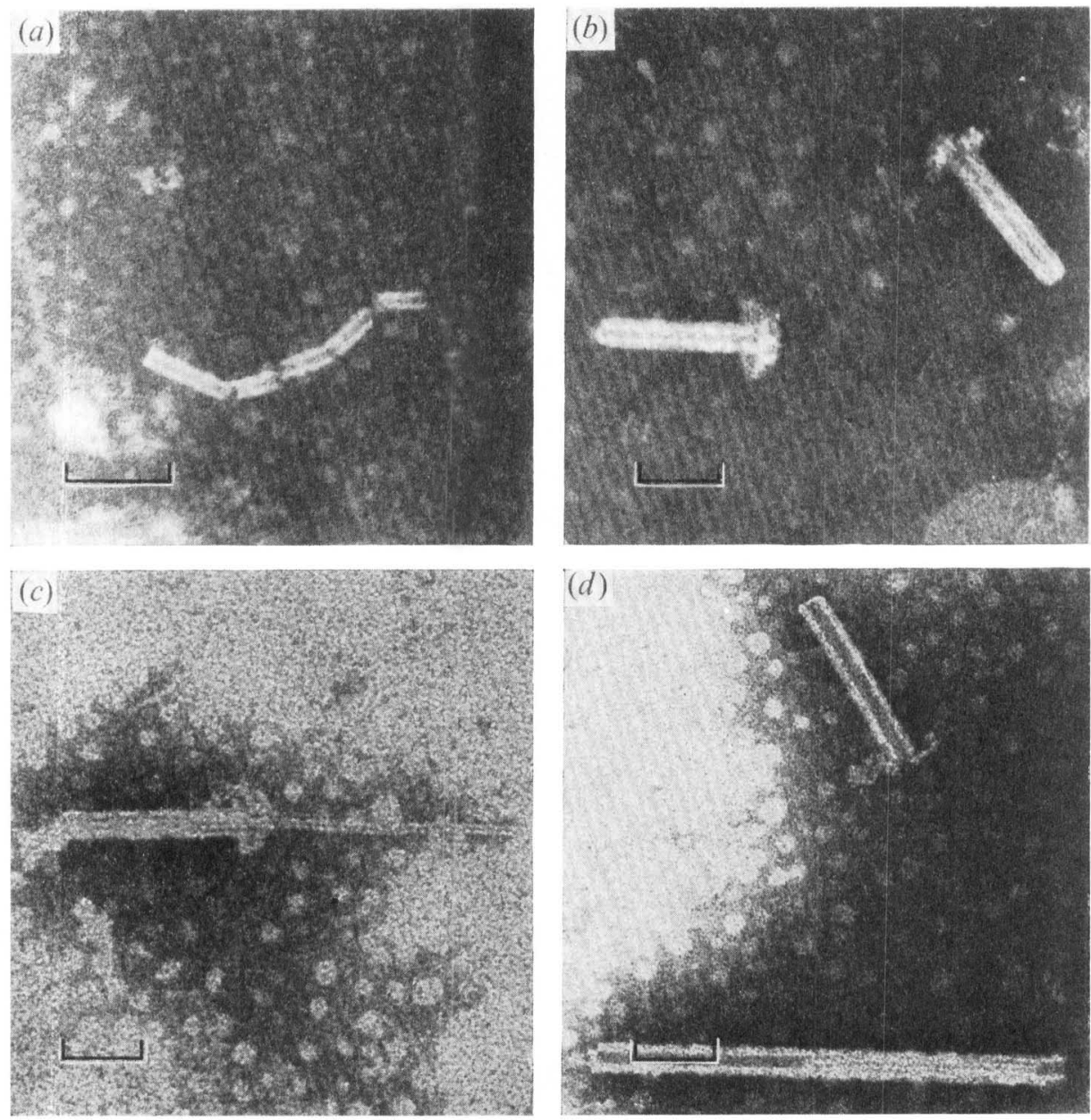

Fig. 3. Negatively stained rhapidosomes. (a) Fragmented rhapidosomes. Note end appendages in $(b)$ and $(d)$, and wicks in $(c)$ and $(d)$. Bar marker $(a)=100 \mathrm{~nm}$; bar markers $(b),(c),(d)=50 \mathrm{~nm}$.

\section{$R N A$ and protein content}

The rhapidosome-rich fraction contained $220 \mu \mathrm{g}$ protein/mg dry wt. RNA determination showed the fraction to contain $18 \mu \mathrm{g} \mathrm{RNA} / \mathrm{mg}$ dry wt, giving an RNA to protein ratio of 0.08 .

\section{Action of various chemical reagents}

When the rhapidosome-rich fraction was treated with RNase, DNase, chloroform, acetone, SDS, SDC, EDTA, Triton X-100 or urea, the integrity of the rhapidosomes was preserved. Prolonged treatment $(24 \mathrm{~h})$ with acid, alkali, or the proteolytic enzymes pronase, trypsin, and chymotrypsin resulted in less well-defined structure, but in all instances, intact rhapidosomes were observed. 

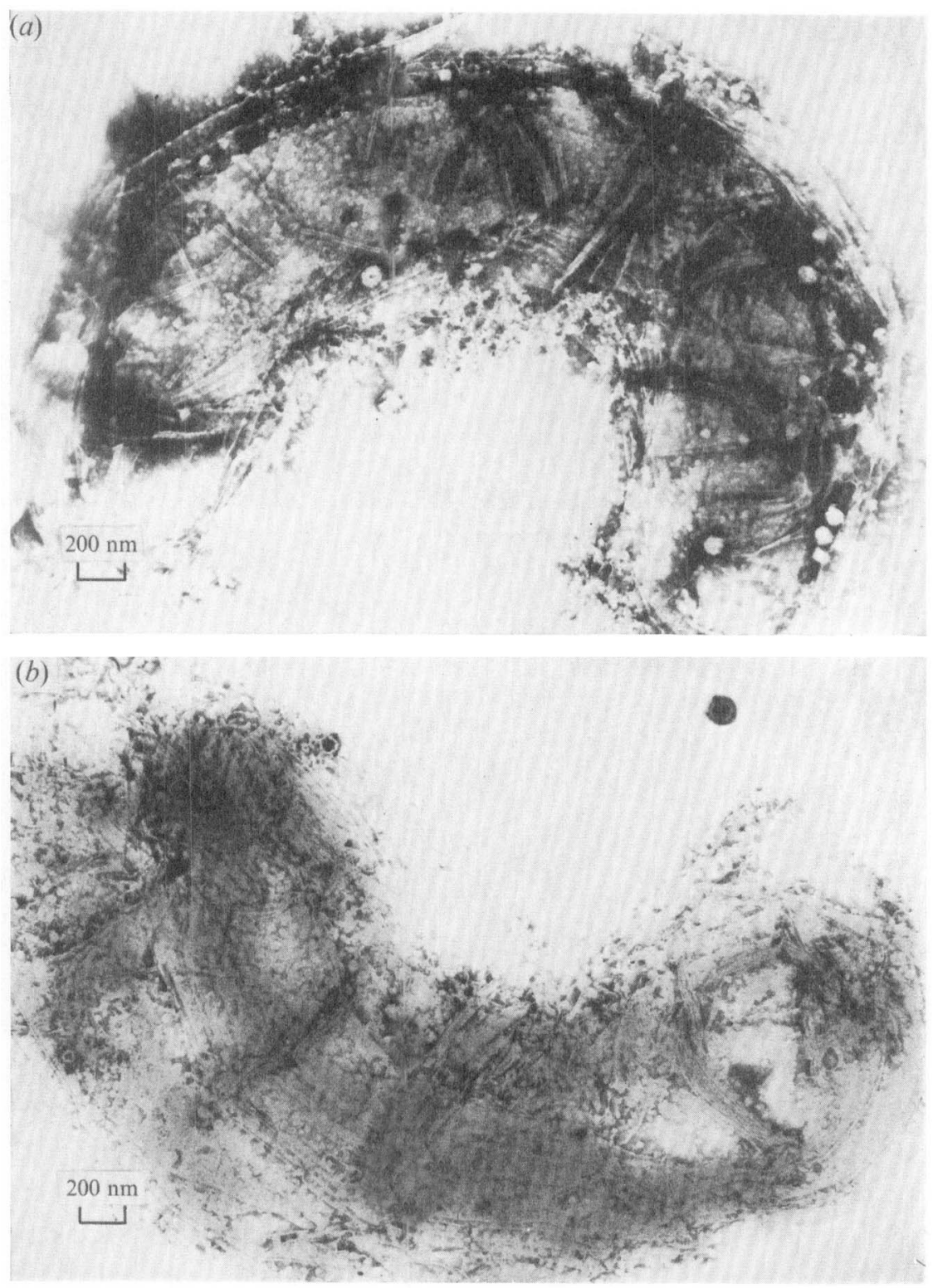

Fig. 4. Negatively stained preparations of mitomycin-lysed cells showing peripherally situated rhapidosomes distinguishable from the parallel folds of the photosynthetic and mesosomal membranes.

\section{Mitomycin induction}

After $6 \mathrm{~h}$ treatment with mitomycin $\mathrm{C}$ most of the cells were partially lysed. Peripherally situated rhapidosomes were seen lying within the cells. They appeared randomly oriented with no apparent attachment to any cell organelle and were easily distinguishable from the parallel folds of the photosynthetic and mesosomal membranes (Fig. 4).

After $24 \mathrm{~h}$ treatment most of the cells were lysed, releasing the rhapidosomes to the supernatant which had a much larger number of rhapidosomes than had supernatants from 


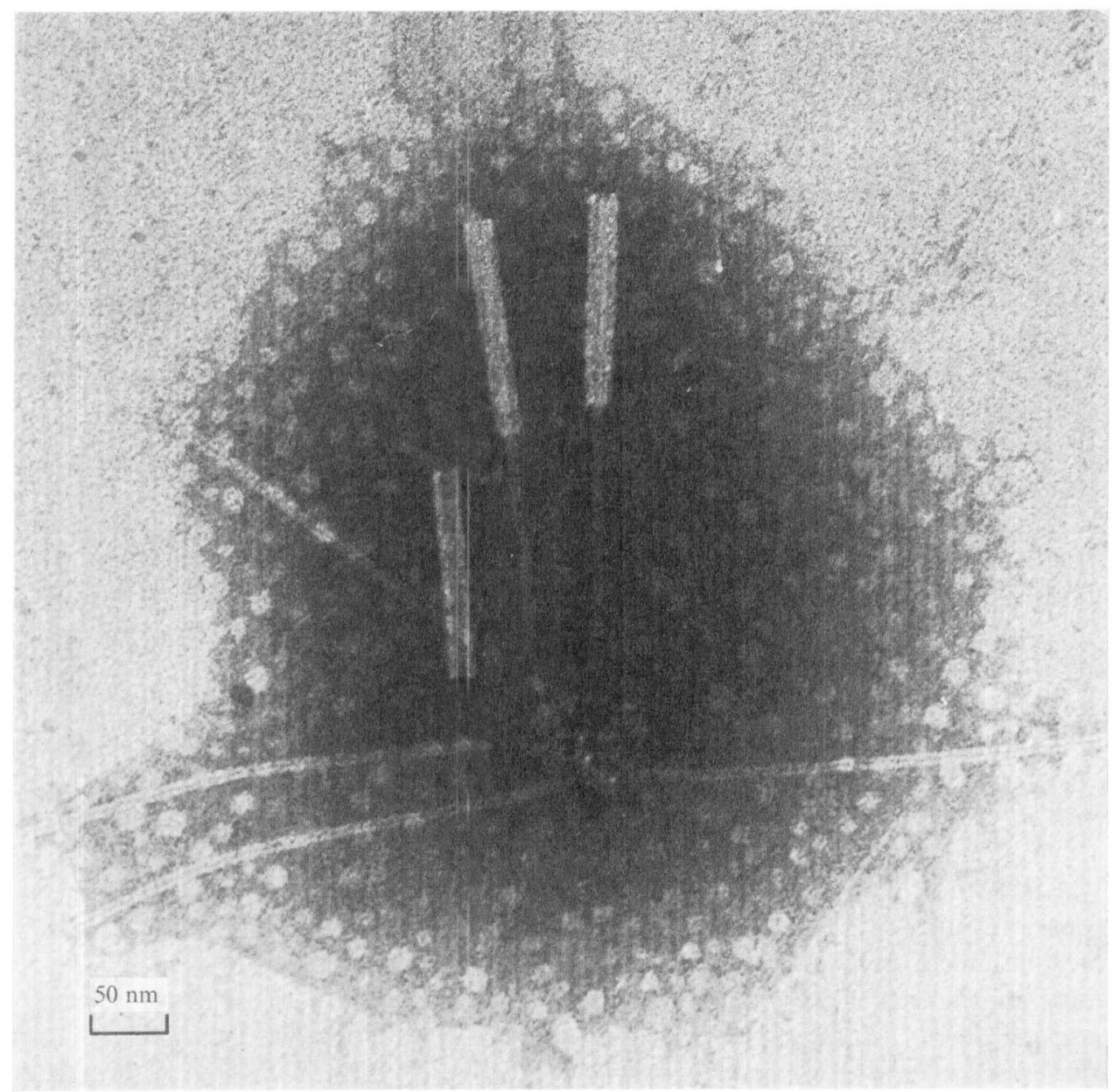

Fig. 5. Negatively stained rhapidosomes from mitomycin-treated cells. Note intact forms with the central core protruding from the sheath.

untreated cultures. A larger number of rhapidosomes present in supernatants from mitomycin C-treated cells were also in the intact form with the central core protruding from the sheath (Fig. 5).

\section{DISCUSSION}

Rhapidosomes, particles morphologically similar to those found in the bacterium Saprospira grandis, were found in and isolated from lysed cultures of Spirulina, the bluegreen structural counterpart of $S$. grandis, hence strengthening the close relationship between these two classes of organisms.

The main difficulty in the purification of the rhapidosomes from Spirulina was contamination by membrane fragments. In Saprospira, which is free of photosynthetic membranes, the rhapidosomes can be successfully purified by a $\mathrm{CsCl}$ gradient (Reichle \& Lewin, I968). For Spirulina, a similar gradient preparation gave no clean separation of rhapidosomes. Similarly, Ficoll and sucrose gradients, of various concentrations, gave banding patterns more related to membrane fragment size than to concentration of rhapidosomes. Even in 
the greatly enriched rhapidosome fraction from the renografin gradient (band II), small fragments of membrane were still present. Neither SDS nor EDTA treatment allowed further purification of Spirulina rhapidosomes. EDTA promoted membrane aggregation, trapping the rhapidosomes among the meshwork of membrane aggregates. Treatment of band II with Triton X-100, followed by layering on a renografin gradient, produced the best purification of rhapidosomes.

Negatively stained preparations show rhapidosomes from Spirulina to consist of two structures, both hollow cylinders. The core is about $350 \mathrm{~nm}$ in length and about $7.5 \mathrm{~nm}$ in diameter with an axial channel about $3.0 \mathrm{~nm}$ wide. The sheath varies in length and is about $24.0 \mathrm{~nm}$ in diameter with a channel about $8.0 \mathrm{~nm}$ wide. These dimensions agree with those reported by previous workers for Saprospira (Lewin, I963; Reichle \& Lewin, 1968). In agreement with Delk \& Dekker's (1972) observation, few intact rhapidosomes were present when compared to free cores and sheaths. In Saprospira, twelve curved projections around the periphery of the sheath in cross-sectional views, and parallel markings at an angle of $15^{\circ}$ to the axis of the sheath in lateral views were observed. These observations strongly support the suggestion that the sheath is made up of a helical array of subunits (Delk \& Dekker, 1972). In our preparations, we were unable to find cross-sectional views although some samples were sonicated for Io min to produce fragments that would rest vertically on the grid.

Rhapidosomes from Spirulina and Saprospira are similar in their remarkable stability. Delk \& Dekker (1972) reported Saprospira rhapidosomes remained intact after prolonged treatment with a large number of reagents including the reagents used in the present study. Density values obtained in gradient studies are also similar. Delk \& Dekker (1972) reported density values of $1 \cdot 32 \mathrm{~g} / \mathrm{cm}^{3}$ for cores, $\mathrm{I} \cdot 295 \mathrm{~g} / \mathrm{cm}^{3}$ for intact rhapidosomes, and $\mathrm{I} \cdot 285$ $\mathrm{g} / \mathrm{cm}^{3}$ for sheaths. A value of $\mathrm{I} \cdot 288 \mathrm{~g} / \mathrm{cm}^{3}$ was determined in our study for a preparation composed mostly of hollow sheaths.

Information concerning the in situ location of the rhapidosomes would help in our understanding of the biological role of rhapidosomes. In partially lysed whole mounts of Saprospira, Correll \& Lewin (I964) found large numbers of randomly oriented rhapidosomes. Similar observations were made on crude lysates of Spirulina. In thin sections, Lewin observed that developing rhapidosomes seemed to be mainly associated with the nuclear region (Lewin \& Kiethe, I965). Thin sections of Spirulina do not show the presence of rhapidosomes (Allen, I972), probably because of the abundant photosynthetic and mesosomal membrane systems within the cells.

The abundance of rhapidosomes in mature or dying cultures and their general resemblance to the tail core and contracted sheath of several bacteriophages have led several investigators to comment on the possible viral role of rhapidosomes. Delk \& Dekker (1972) compared the dimensions of a number of phage-related particles and suggested that the almost constant diameter for the core $(7.5$ to $9.0 \mathrm{~nm})$ and sheath $(20.0$ to $28.0 \mathrm{~nm})$ strongly linked rhapidosomes to this class of particles. Their amino acid composition and stability to denaturing conditions are also similar to those of phage-related structures (Delk \& Dekker, 1972). Reichenbach (1967) regards rhapidosome-like particles (consisting of a core, a contractile sheath, and a basal plate with spikes and fibres) in Archangium violaceum, a myxobacterium, as degenerate bacteriophage because he could induce increases in the yield of the phage with mitomycin C. Only the tail of this defective phage is formed; phage heads were never observed. Similarly, Clark-Walker (1969) reported that in Spirillum itersonii, mitomycin $\mathrm{C}$ and u.v. light induced the formation of microcysts which contained phage tail parts, rhapidosomes, and a granular substance not seen in normal cells. Again, 
complete virus particles were not formed. Clark-Walker (I969) suggested that rhapidosomes may be products of a defective phage genome, i.e. a form of polysheath arising by a selfassembly of excess sheath subunits.

The results of our induction experiments indicate that mitomycin $\mathbf{C}$ causes the prompt lysis of Spirulina and an increase in the number of rhapidosomes in the cells, suggesting that the rhapidosomes of Spirulina may be defective phages.

Since no proof of virulence of rhapidosomes has been demonstrated, there is the alternative hypothesis that they are integral components of normal cells. Their strong resemblance to the microtubules of ubiquitous distribution might suggest that they fulfil a general structural or functional role such as motility. Each procaryotic microbe in which structures similar to rhapidosomes have been demonstrated has some degree of motility, be it a gliding apochlorotic cyanophyte, a flexibacterium, or the contractile tail of a phage. Pate et al. (1967) have further suggested that the rhapidosomes in Chondrococcus columnaris may be derived from the distintegration of the mesosomal membrane. So far, Spirulina is the only blue-green alga found to have mesosomes (Allen, 1972). All of these hypotheses for the role of rhapidosomes are consistent with the data presented.

It can be concluded that Spirulina contains rhapidosomes which are similar in structural and chemical properties to those formed in Saprospira. Lewin (I962) considers Saprospira to be an alga assigned within the division Cyanophyta next to the genus Spirulina, while Stanier et al. (I97I) consider blue-green algae to be bacteria. Both are helical, multicellular, spiral organisms; Saprospira is apochlorotic and heterotrophic, while Spirulina is photoautotrophic, containing chlorophyll $a$ and phycobiliprotein. The results of this study describe another shared structural component, further evidence that the organisms are closely related.

This work was supported by National Science Foundation grant GB 2299I, a Research Corporation Brown-Hazen grant and Wellesley College. We gratefully acknowledge the assistance of Nancy Pearson and thank Dr G. F. Gauthier and Dr H. A. Padykula for the use of the facilities of the Electron Microscope Laboratory.

\section{REFERENCES}

Allen, M. M. (1968). Simple conditions for growth of blue-green algae on plates. Journal of Phycology 4, $\mathrm{I}-4$.

Allen, M. M. (1972). Mesosomes in blue-green algae. Archiv für Mikrobiologie 84, 199-206.

Bradley, D. E. \& Dewar, C. A. (1966). The structure of phage-like objects associated with non-induced bacteriocinogenic bacteria. Journal of General Microbiology 45, 399-408.

Clark-Walker, G. D. (1969). Association of microcyst formation in $S$. itersonii with the spontaneous induction of a defective bacteriophage. Journal of Bacteriology 97, 885-892.

Correll, D. L. \& Lewin, R. A. (1964). Rod-shaped ribonucleoprotein particles from Saprospira. Canadian Journal of Microbiology 10, 63-74.

DelK, A. S. \& DekKer, C. A. (I969). Rhapidosomes: Absence of a highly 2'-O-methylated RNA component. Science, New York I66, I646-I647.

DelK, A.S. \& DekKer, C. A. (I972). Characterization of rhapidosomes of Saprospira grandis. Journal of Molecular Biology 64, 287-295.

HuXley, H. E. \& ZubAY, G. (I960). Electron microscope observations on the structure of microsomal particles from E. coli. Journal of Molecular Biology 2, 10-18.

vaN ITERSON, W., Hoeniger, J. F. M. \& VAN ZANTEN, E. N. (1967). A 'microtubule' in a bacterium. Journal of Cell Biology 32, I-IO.

LewIN, R. A. (1962). Saprospira grandis Gross: And suggestions for reclassifying helical, apochlorotic, gliding organisms. Canadian Journal of Microbiology 8, 555-563. 
LEwIN, R. A. (1963). Rod-shaped particles in Saprospira. Nature, London 198, 103-104.

LEWIN, R. A. \& KIETHE, J. (1965). Formation of rhapidosomes in Saprospira. Canadian Journal of Microbiology II, 935-938.

Moody, M. F. (1967). Structure of the sheath of bacteriophage T4. Journal of Molecular Biology 25, 167-200.

Pate, J. L., Johnson, J. L. \& ORdal, E. J. (I967). The fine structure of Chondrococcus columnaris. II. Structure and formation of rhapidosomes. Journal of Cell Biology 35, I 5-35.

Price, A. R. \& Rottman, F. (1970). Nucleic acids from S. grandis: the absence of 2'-o-methyl RNA. Biochimica et biophysica acta 199, 288-29I.

Reichendach, H. (1967). Die wahre Natur der Myxobakterien 'rhapidosomen'. Archiv für Mikrobiologie $56,371-383$.

Reichle, R. E. \& Lewin, R. A. (1968). Purification and structure of rhapidosomes. Canadian Journal of Microbiology I4, $211-220$.

RuCINSKY, T. E. \& Cota-Robles, E. H. (1973). The intracellular organization of bacteriophage tail-like particles in cells of Chromobacterium violaceum following mitomycin $\mathrm{C}$ treatment. Journal of Ultrastructure Research 43, 260-269.

Stanier, R. Y., Kunisawa, R., Mandel, M. \& Cohen-Bazire, G. (I97I). Purification and properties of unicellular blue-green alga (order Chroococcales). Bacteriological Reviews 35, I7I-205.

TAmin, H. \& Gilvarg, C. (I966). Density gradient centrifugation for the separation of sporulating forms of bacteria. Journal of Biological Chemistry 241, 1085-1090.

Yамамото, T. (1967). Presence of rhapidosomes in various species of bacteria and their morphological characteristics. Journal of Bacteriology 94, 1746-1756. 